\title{
COMPARATIVE STUDY ON TAX COMPLIANCE SOFTWARE
}

\author{
Pooja Mhetre', Pooja Mutha', Vaidehi Lad ${ }^{3}$ \\ ${ }^{I}$ Student, Computer Department, P.E.S. Modern College of Engineering, Maharashtra, India \\ ${ }^{2}$ Student, Computer Department, P.E.S. Modern College of Engineering, Maharashtra, India \\ ${ }^{3}$ Student, Computer Department, P.E.S. Modern College of Engineering, Maharashtra, India
}

\begin{abstract}
Market place as it is commonly known, is a centralised location that has a host of generic customised programs/extensions, in addition to other accounting products and upgrades, Our Tax Compliance system would be an internet based software. It is an application like Gmail, Facebook which can run on any browser and on any devices. For any organization our software will be serving as an online application (web based-using cloud) to store the data in accounting format and generation of reports in standardized format. Though so many accounting softwares are available in the market, they are lacking in some features. so the comparative analysis is required to determine which software holds the best market position. By doing the analysis it is essential to overcome those drawbacks and to design the product which comprises of all the necessary features. So the proposed system 'BOOKSOFACCOUNTS' will serve as an efficient accounting software.
\end{abstract}

Keywords: Accounting, Inventory, Taxation, Payroll system

\section{INTRODUCTION}

This project deals with storing each piece of information which is generated (whether from internal source or external source) on cloud. It avoids the data redundancy by providing standards to store the information BOOKSOFACCOUNTS would be standardized cloud based accounting and database management system catering to all needs of small and medium enterprises. On the basis of functions and value addition perspective it can be divided into the following products.

1) Accounting and ERP products:-

1.1) Accounting Compliances with report generation

1.2) Inventory Management system

1.3) Payroll Processing

2) Statutory products:-

2.1) Computation of Taxation laws i.e State VAT Laws, Excise duties, Income Tax, etc

2.2) Generation of XML for Return filing

3) Management Products:-

3.1) Various types of products

3.2) Internal chat system

3.3) Record of customer enquires

For designing of the system, desktop and web application will be created and same data storage will be used for both the applications using cloud technology.

Purposes of using cloud for our system:-

1) It increases storage without buying more hardware.

2) Sync local and remote folders

3) Focus on app logic instead of permissions

4) Direct URLs reduce on web server.

\section{LITERATURE REVIEW}

Comparative study:-

Features of existing accounting softwares are as follows.

\begin{tabular}{|c|c|c|}
\hline $\begin{array}{l}\text { Sr } \\
\text { no. }\end{array}$ & Particulars & Features \\
\hline 1. & Tally ERP 9 & $\begin{array}{l}\text { Tally.ERP } 9 \text { is a business } \\
\text { accounting software for } \\
\text { accounting, inventory, payroll. It is } \\
\text { economical and one of the most } \\
\text { popular solution available in the } \\
\text { industry. }\end{array}$ \\
\hline 2. & Quick Books & $\begin{array}{l}\text { With Quickbooks, you can } \\
\text { maintain complete accounts online. } \\
\text { This product will help entrepernuer } \\
\text { make their business more } \\
\text { streamlined, methodical and } \\
\text { controled. }\end{array}$ \\
\hline 3. & Busy & $\begin{array}{l}\text { Busy accounting package is an } \\
\text { solution for Small and Medium } \\
\text { businesses. It has more than } \\
1,20,000 \text { installations, and is one of } \\
\text { the leading accounting softwares in } \\
\text { India. }\end{array}$ \\
\hline 4. & Profit Books & $\begin{array}{l}\text { ProfitBooks is amazingly simple } \\
\text { and fastest amongst the list of } \\
\text { accounting software for small } \\
\text { businesses. }\end{array}$ \\
\hline 5. & $\begin{array}{l}\text { Wave } \\
\text { Accounting }\end{array}$ & $\begin{array}{l}\text { Wave's accounting tools are } 100 \% \\
\text { free, secure, and accountant- } \\
\text { approved. It is one of the best cloud } \\
\text { based solution available }\end{array}$ \\
\hline 6. & Marg & $\begin{array}{l}\text { Userfriendly, flexibility, report } \\
\text { generation, graph generation }\end{array}$ \\
\hline
\end{tabular}


As many softwares are available in market related to accounting area. but they do have certain drawbacks.

\begin{tabular}{|l|l|l|l|l|l|l|}
\hline S. No. & Name of the Function & Tally & Quick Books & Profit Books & Marg Accounting & Busy \\
\hline 1. & Cloud Based & No & Yes & Yes & Yes & Yes \\
\hline 2. & Statutory Compliances & No & No & No & No & No \\
\hline 3. & Audit Trial & Yes & No & Yes & Yes & Yes \\
\hline 4. & Indian Accounting Procedure & Yes & No & Yes & Yes & No \\
\hline 5. & Additional Reporting Capabilities & No & No & No & No & No \\
\hline 6. & Multiple TAB Option & No & Yes & Yes & Yes & Yes \\
\hline 7. & Risk Covered when Server Crash & No & Yes & Yes & Yes & Not Guaranteed \\
\hline
\end{tabular}

Some of the common drawbacks of the existing systems are overcome in proposed system. Those are as follows :

1) Data scalability

2) System gets hang

3) For remote acess the software should be operated on ther system. Xero and Quickbook software do not hav the facility of backtracking the transaction. Our software will be designed in such a way that it will come over all these drawbacks.

4) It will be applicable to all the fields particularly manufacturing area.

5) It has its own database

6) Data is corrupted if system is not closed properly .

7) It needs to be installed.

Flow of system:- No Other Software's or Application is required to Install in Computer System to make this Website Run

Logging System:- In the User Logging we create authorisation to maintain data privacy of the owner with employees

Data Entry System:- At the time of data entry there would be limited number of accounts not like tally making the report preparation easy. The same would be based on the basis of Accounts appearing in format of Schedule 6 and Income Tax Returns.

- It will also facilitate in calculation of Reports of Service Tax, TDS, and Sales Tax etc.

- So will totally control the input made to system

No Direct XML generations for Statutory Compliances which results in data duplication
1. Excise Returns
2. Service Tax returns
3. Sales Tax Returns
4. Income Tax Returns
5. TDS Returns
- Income Tax Return
- VAT Returns
- Service Tax returns

\section{REPORT GENERATION SYSTEM}

- Like Tally a limited number of reports can be generated from the accounting software

- These Reports can be exported to excel, PDF etc.

- Result Oriented reports format would be defined by using the terms of business intelligence.
- There would be an Option like "Print Books of Accounts " in which if we give period range then the entire report can be converted into PDF and the same can be used in assessments and proceedings.

\subsection{Inventory System}

- Real time Update of Stock Availability in one click.

- Identification of Obsolete and Non Moving Stock i.e. we can highlight the old unsold stock lying in the godown.

- Stock Valuation at any date.

- Provide Readymade data for physical checking of stock

The Inventory Info menu, lists the inventory masters like Stock Group, Stock Items, Units of Measure of the company, using which you can create, alter and display the inventory master details.

\subsection{Payroll system}

System's Payroll is fully integrated with Accounting so as to give the users the benefit of simplified Payroll processing and accounting. It enables users to set up, implement and process Payroll with simple to complex criteria, as per the organization's requirements. The predefined processes available in product helps automation of the Payroll processing without any errors. System also provides management related Information reports and statutory Forms and reports in the prescribed formats viz., Pay Slip, Payroll Statements, Attendance and Overtime Registers, Gratuity, PF, ESI, PT, Income Tax, Expat Reports and so on. Statements, Attendance and Overtime Registers, Gratuity, PF, ESI, PT, Income Tax, Expat Reports and so on.

\subsection{Taxation}

This module is comprises of service tax,TCS,TDS, VAT, etc. Service Tax is a indirect tax imposed on specified services (taxable services) provided by a service provider (Company, Individual, Firm etc.). TCS is the Tax Collected at Source by the seller. TDS means Tax Deducted at Source. The concept of TDS was introduced in the Income Tax Act, 1961, with the objective of deducting the tax on an income, at the source of income. It is one of the methods of collecting Income Tax, which ensures regular flow of revenue to the Government (collector) from the buyer/ lessee (collectee/ payee). VAT stands for Value Added Tax. In this system, the tax is levied on the value of the good and charged at every level of Value addition i.e, on the Value added portion of goods at each level. Central Sales Tax is a tax on Sale levied by Central Government under the provisions of Central Sales Tax Act, 1957. 


\section{CONCLUSION}

By doing the analysis of the features and drawbacks of the existing softwares, we can say -

1) No multiple software requirements for different business functions.

2) Ready availability of requisite information as the same is stored in cloud .

3) Every bit of information and data generated would be stored in the organization and the same will not be duplicated.

4) Management can monitor business with less manpower.

\section{ACKNOWLEDGEMENTS}

This research paper has been made possible due to the guidance and support of Mrs. Manisha Petare who have helped us in all aspects regarding the subject. We would like to express our gratitude for their invaluable insights and encouragement. We would also like to thank all our teachers who have helped us in various concepts related to the paper.

\section{REFERENCES}

[1]. Garrison Greenwood, Editor-in-chief(2009 present),Department of Electrical and Computer Engineering,Portland state university,portland "IEEE TRANSACTIONS ON EVOLUTIONARY COMPUTATION". [2]. Salleh K,Fac of Accountancy,univ,teknol,MARA shah Alam,Malasia,"Accountants and Technologies:knowledge and management Model".

[3]. Sadigi,M;Dept.of.inf.tech.manage,Tehran univ,Iran,"Accounting system on cloud:A case study".

[4]. http://cloudcomputing.ieee.org/publications

[5]. http://financialsoft.about.com/od/smallbusiness/ss/The-

Best-Online-Accounting-Software-For-The-Self-

Employed_3.htm

[6]. https://www.waveapps.com/about-us/

[7]. http://yourfinancebook.com/accounting-software-smallbusinesses/

[8]. http://www.lynda.com/Business-Accountingtutorials/Accounting-Fundamentals/158665-2.html 